Vol. 3 No. 1 April 2020

\title{
PERBANDINGAN HUKUM PAJAK DAN ZAKAT MENURUT SYARIAH DAN NEGARA
}

\author{
Fatmawati Zahroh \\ UIN Maulana Malik Ibrahim Malang \\ fatmawati.zahroh.fe@uin-malang.ac.id \\ Harkaneri \\ UIN Sultan Syarif Kasim Riau \\ harkaneri@uin-suska.ac.id
}

\begin{abstract}
This article describes how to compare tax and zakat law from the perspective of sharia (Islamic law) and state (positive law). There are many similarities and differences between this tax and zakat, in terms of both collectors and collectors. According to article 1 of the 2009 KUP Law on taxes and Law No. 23 of 2011 concerning zakat and its management. This article uses the literature study method to compare and describe existing legislation as well as some differences between tax and zakat. With the results and discussion that actually this tax and zakat if synergized will become two very large state revenues so that they can finance state expenditures, but this state expenditure will be divided into routine expenditures and expenditures for people who are unable to meet the obligations of a muzakki (compulsory zakat) to mustahik (recipient of zakat). If synergized like that, the amil zakat and the government must be observant in differentiating these expenditures to be channeled to those who are entitled to and expenditures as appropriate for the State Budget.
\end{abstract}

Keywords: Tax and Zakat, Sharia Law, State Law

\begin{abstract}
ABSTRAK
Artikel ini menggambarkan tentang bagaimana perbandingan hukum pajak dan zakat dari perspektif syariah (hukum Islam) dan negara (hukum positif). Ada banyak persamaan dan perbedaan antara pajak dan zakat ini, dari segi pemungut maupun yang dipungut. Menurut pasal 1 UU KUP tahun 2009 tentang pajak serta UU No. 23 tahun 2011 tentang zakat dan pengelolaannya. Artikel ini menggunakan metode studi pustaka guna membandingkan dan menjabarkan perundangan yang ada serta beberapa perbedaan antara pajak dan zakat. Dengan hasil dan pembahasan bahwa sebenarnya pajak dan zakat ini bila disinergikan akan menjadi dua penerimaan negara yang sangat besar sehingga mampu membiayai pengeluaran negara, akan tetapi pengeluaran negara ini akan dibedakan menjadi pengeluaran rutin dan pengeluaran bagi masyarakat yang tidak mampu untuk memenuhi kewajiban seorang muzakki (wajib zakat) kepada mustahik (penerima zakat). Jika disinergikan seperti itu maka amil zakat beserta pemerintah harus jeli dalam membedakan pengeluaran ini untuk disalurkan kepada yang berhak dan pengeluaran sebagaimana mestinya untuk APBN.
\end{abstract}

Kata Kunci : Pajak dan Zakat, Hukum Syariah, Hukum Negara 


\section{PENDAHULUAN}

Antara pajak dan zakat dilihat dari hukum syariah dan hukum negara sangatlah berbeda, akan tetapi memiliki kesamaan ditarik dari masyarakat untuk keperluan umat. "Pajak adalah kontribusi wajib kepada negara yang terutang oleh orang pribadi atau badan yang bersifat memaksa berdasarkan undang-undang dengan tidak mendapatkan imbalan secara langsung untuk keperluan negara bagi sebesar-besarnya kemakmuran rakyat" (Pasal 1 UU KUP). Sedangkan zakat adalah kewajiban umat Islam untuk membayar sejumlah uang tertentu sesuai dengan ketentuan hukum syariah. Menurut Ramadhan, bahwa pajak dan zakat bisa diintegrasikan untuk membiayai pengeluaran negara, karena ada beberapa pos dalam APBN yang bisa digolongkan untuk pengeluaran dari penerimaan zakat, sayangnya pemerintah belum melakukan integrasi tersebut, jika dilakukan maka akan membantu pemerintah dalam menanggulangi defisit APBN. ${ }^{1}$ Sedangkan Tahir dan Triantini menyebutkan bahwa integrasi antara pajak dan zakat akan menjadikan perekonomian akan maju jika konsep dan aturannya jelas, sebabtelah terjadi pertumbuhan yang signifikan dalam lembaga pelayanan pengembangan distribusi zakat. ${ }^{2}$ Serta menurut Wahid yang menjelaskan dalam jurnalnya bahwa di Indonesia terjadi perkembangan dan pertumbuhan zakat dengan meningkatnya jumlah Badan Amil Zakat dari tahun ke tahun, diprediksi jika terjadi integrasi antara pajak dan zakat maka akan menjadi alat kesejahteraan ekonomi dan sosial bagi masyarakat. Hal ini akan menjadikan zakat sama kedudukannya dengan pajak, yang harus ada konsep dan aturan yang jelas supaya terlaksana alur perekonomian yang maju. ${ }^{3}$

Dengan 3 penelitian terdahulu tentang integrasi antara pajak dan zakat ini yang menggambarkan bahwa jika adanya peraturan dan konsep yang jelas yang dibuat pemerintah untuk memungut dari wajib pajak dan wajib zakat yang dikelola pemerintah maka akan terjadi kemajuan ekonomi yang signifikan karena sebagian dari APBN akan ditanggung oleh penerimaan zakat sehingga dapat mengurangi defisit anggaran yang

\footnotetext{
${ }^{1}$ Muhammad Rheza Ramadhan. Integrasi Pajak dan Zakat di Indonesia. Jurnal Ekonomi Islam Vol. 8 No. 1 Januari-Juni 2017: 77-94.

2 Masnun Tahir dan Zusiana Elly Triantini. Integrasi Zakat dan Pajak di Indonesia dalam Tinjauan Hukum Positif dan Hukum Islam. Jurnal Al-'Adalah Vol. XII, No. 3 Juni 2015: 507-524.

${ }^{3}$ Moh. Abdur Rohman Wahid. Integrasi Pajak dan Zakat di Indonesia Perspektif Hukum Islam dan Hukum Positif. Jurnal Ekonomi Islam el-Jizya Vol. 4 No.1 Januari-Juni 2016: 27-58.
} 
selama ini terjadi. Untuk itulah artikel ini akan memberikan penjelasan perbandingan antara pajak dan zakat dari perspektif hukum syariah (hukum Islam) dengan huum negara (hukum positif, sehingga muncul dengan judul "Perbandingan Hukum Pajak dan Zakat menurut Syariah dan Negara."

\section{METODE PENELITIAN}

Metode yang digunakan dalam artikel ini adalah metode studi pustaka untuk membandingkan hukum pajak dan zakat menurut syariah dan negara. Yang dimaksud dengan studi kepustakan ialah segala usaha yang dilakukan oleh peneliti untuk menghimpun informasi yang relevan dengan topik atau masalah yang diteliti. Teori-teori yang mendasari artikel ini sesuai dengan penelitian sebelumnya atau artikel terkait dengan judul. Dengan studi kepustakaan maka artikel ini dapat memanfaatkan segala informasi yang terkait secara relevan.

Tujuan Studi Pustaka

1. Masalah yang dicari dapat disajikan dengan data bukti dan pernyataan.

2. Menjadikan informasi sebagai dasar yang relevan sesuai dengan isi artikel yang diteliti.

3. Melakukan komparasi dengan teori yang relevan.

Peranan Studi Kepustakaan

Hubungan antara masalah, penelitian-penelitian yang relevan dan teori akan menjadi lebih jelas. Selain itu penelitian akan lebih ditunjang, baik oleh teori-teori yang sudah ada maupun oleh bukti nyata, yaitu hasil-hasil penelitian, kesimpulan dan saran. Sumber Studi Kepustakaan

Sumber informasi yang dijadikan bahan studi kepustakaan antara lain:

1. Jurnal Penelitian

Jurnal penelitian merupakan hasil dari kajian penelitian yang menjadi acuan bagi peneliti untuk pengetahuan baru dan bahan kajian baru.

2. Buku

Buku adalah sumber ilmu pengetahuan yang dapat memberikan bahan kajian dasar bagi penulis. 


\section{Surat Kabar Dan Majalah}

Surat kabar dan majalah menjadi kajian yang paling mudah didapat dalam mencari informasi untuk kajian pustaka.

4. Internet

Internet merupakan sarana yang sering diakses dan mempermudah bagi peneliti dalam mencari kajian ilmu pengetahuan dalam era 4.0 ini dukungan internet sangatlah dibutuhkan.

Strategi Studi Kepustakaan

1. Mengklasifikasikan variabel yang ada..

2. Mencari variabel pada "subject encyclopedia".

3. Memilih deskripsi bahan-bahan yang diperlukan dari bahan-bahan yang tersedia. ${ }^{4}$

\section{PEMBAHASAN}

Beberapa persamaan pajak dan zakat ialah :

1. Sama-sama wujud kewajiban rakyat kepada pemungut $=>$ pajak adalah kewajiban warga negara kepada negara yang besarannya sesuai dengan UU Perpajakan. Sedangkan zakat juga merupakan suatu kewajiban seorang muslim karena ketentuan dari Alloh.

2. Sama-sama disetorkan kepada lembaga yang terkait $\Rightarrow>$ pajak wajib dibayarkan wajib pajak kepada Dirjen Pajak sebagai lembaga resmi milik negara. Begitu juga dengan zakat disetorkan kepada badan amil zakat yang telah ditunjuk.

3. Sama-sama tidak mendapatkan imbalan secara langsung $\Rightarrow$ wajib pajak tidak diberi imbalan langsung setelah menyetor pajak kepada pemerintah. Begitu juga dengan pembayar zakat, muzakki tidak mendapat imbalan secara langsung karena disalurkan kepada mustakhik zakat yang memang berhak menerimanya..

4. Memiliki tujuan kemanusiaan dan kemasyarakatan $\Rightarrow$ pajak dipergunakan untuk kepentingan bersama yang telah dirancang dalam APBN. Pada pembayaran zakat, dana

\footnotetext{
${ }^{4}$ Samhis Setiawan. 2019. Studi Kepustakaan-Pengertian, Tujuan, Peranan, Sumber dan Strategi di https://www.gurupendidikan.co.id/studi-kepustakaan-pengertian-tujuan-peranan-sumber-strategi/. Diakses pada 29/01/2020
} 
yang ada dipakai untuk urusan agama, sosial, dan meningkatkan kesejahteraan orang banyak.

Beberapa perbedaan pajak dan zakat:

1. Zakat berpedoman pada al-Quran. Sedangkan pajak berpegangan pada UndangUndang Perpajakan yang berlaku di Indonesia.

2. Zakat merupakan ibadah yang jika melanggarnya tidak akan dikenai hukuman secara langsung. Sedangkan pajak merupakan kewajiban yang jika tidak dilaksanakan akan menerima sanksi dan hukuman administratif serta pidana pajak secara langsung dari negara.

3. Penentuan nisab pada zakat ditetapkan oleh Allah SWT dan Rasul-Nya dan tidak bisa berubah. Sedangkan pada zakat, bersarannya ditentukan berdasarkan kebijakan pemerintah dan bisa berubah.

4. Zakat bersifat permanen dan tetap dengan aturan yang sama dari masa ke masa. Sedangkan pajak bisa mengalami perubahan peraturan tergantung kondisi dan juga kebijakan pemerintah.

5. Pos-pos penyaluran zakat sudah ditetapkan dalam Al-Quran dan sampai kapanpun penerimanya tetap pada pos tersebut. Sedangkan pajak, penyalurannya bisa bersifat fleksibel, tergantung pada kebutuhan dan kondisi negara dengan cakupan yang lebih luas, termasuk pembangunan dan keamanan.

6. Jenis zakat yaitu zakat fitrah dan zakat maal. Sedangkan jenis pajak yaitu PPh, PBB, Pajak Materai, Pajak Daerah, Retribusi Daerah, Retribusi Jasa Umum, dan Retribusi Jasa Usaha. ${ }^{5}$

Jika dilihat dari hukum Syariah dan Negara maka pajak dan zakat ini berbeda tidak hanya dipandang dari hal persamaan dan perbedaan saja, akan tetapi dilihat dari segi hukumnya. Hukum yang ada yaitu Syariah dan Negara, berikut ini perbedaan yang ada di antara pajak dan zakat:

${ }^{5}$ Thidi. 2018. Persamaan dan Perbedaan Pajak dengan Zakat di https://thidiweb.com/persamaandan-perbedaan-pajak-dengan-zakat/. Diakses tanggal 29/01/2020 


\begin{tabular}{|l|l|l|}
\hline \multicolumn{1}{|c|}{ Perbedaan } & \multicolumn{1}{|c|}{ Hukum Syariah } & \multicolumn{1}{c|}{ Hukum Negara } \\
\hline Pajak & $\begin{array}{l}\text { Pajak adalah pungutan kepada } \\
\text { masyarakat bila baitul maal } \\
\text { kosong. }\end{array}$ & $\begin{array}{l}\text { Pajak adalah pungutan kepada } \\
\text { masyarakat yang merupakan } \\
\text { sumber penerimaan negara. }\end{array}$ \\
\hline Pengertian & $\begin{array}{l}\text { Besaran pajak diserahkan pada } \\
\text { individu masing-masing akan } \\
\text { membayar berapa. }\end{array}$ & $\begin{array}{l}\text { Besaran pajak telah diatur } \\
\text { dalam UU Perpajakan. }\end{array}$ \\
\hline Besaran & Orang mampu dan kaya. & $\begin{array}{l}\text { Semua warga negara yang } \\
\text { melakukan usaha dan tergolong } \\
\text { subjek pajak yang diatur dalam } \\
\text { UU Perpajakan. }\end{array}$ \\
\hline Subjek & $\begin{array}{l}\text { Harta berlebih yang dimiliki } \\
\text { oleh orang mampu dan kaya. }\end{array}$ & $\begin{array}{l}\text { Harta yang telah digolongkan } \\
\text { UU Perpajakan. }\end{array}$ \\
\hline $\begin{array}{l}\text { Penggunaan untuk } \\
\text { pengeluaran negara }\end{array}$ & $\begin{array}{l}\text { Semua pengeluaran negara } \\
\text { yang bersumber dari baitul } \\
\text { maal. }\end{array}$ & $\begin{array}{l}\text { Semua pengeluaran negara } \\
\text { tetapi dibantu oleh bantuan luar } \\
\text { negeri dan penerimaan bukan } \\
\text { pajak untuk memenuhi dan } \\
\text { menutup pengeluaran negara } \\
\text { yang telah dirancang di APBN. }\end{array}$ \\
\hline Sumber hukum & Hukum Islam. & Hukum positif. \\
\hline
\end{tabular}

Hukum Islam klasik menyebutkan bahwa adanya tiga untuk sistem pemungutan pajak. Pertama, jizyah (pajak kepala) adalah pajak yang diharuskan untuk dibayar oleh orang non muslim dalam naungan pemerintahan Islam (kafir zimmi) dengan mematuhi segala perundangan dan auran yang harus dijalankan secara sukarela oleh non muslim sehingga pemerintah Islam harus menyamakan kedudukan mereka dalam hal perlindungan, keselamatan dan kemerdekaan serta hak asasi mereka di dalam menjalankan kehidupannya sehari-hari. Akan tetapi jika menghadapi negara non-Islam ada 3 pilihan yang meliputi yaitu mau masuk Islam, membayar jizyah atau diperangi. Jika mau masuk Islam berarti mereka akan aman dan disamakan kedudukannya seperti masyarakat muslim lainnya. Akan tetapi jika tidak mau masuk Islam berarti ada 2 kemungkinan pilihan yang bisa diambil yaitu membayar jizyah atau tidak ada cara lain dengan diperangi.

Kedua, kharaj, yaitu pajak bumi. Pengenaan kharaj ini untuk tanah kepemilikan muslim akibat peperangan kemudian dikembalikan kepada pemilik yang berhak atas tanah tersebut dan sebagai imbalannya maka pemilik tanah itu membayar pajak bumi kepada pemerintah Islam. 
Ketiga, 'usyur, yaitu pajak perdagangan, atau bea cukai (pajak impor dan ekspor). Jika dilihat dalam pemerintahan ada banyak sekali pengeluaran yang dibutuhkan untuk menjalankan roda pemerintahan, hal ini menjadikan pemerintah untuk senantiasa mencari sumber dana yang bisa dibilang cukup besar yang berarti tidak hanya dari segi zakat tetapi juga membolehkan pemungutan pajak. Jika dilihat dari aspek sifat, asas, sumber, sasaran, bagian, kadar, prinsip dan tujuannya pajak memang memiliki perbedaan dengan zakat. Akan tetapi, dalam beberapa hal secara substansial dapat ditemukan persamaan antara pajak dengan zakat. Keduanya mengandung unsur paksaan, dikelola oleh suatu lembaga tertentu, tidak ada imbalan yang langsung diterima secara nyata, dan keduanya memiliki semangat perekonomian umat yang sama. Secara spesifik Yûsuf al-Qaradhawi menyebut bahwa zakat adalah ibadah. Ia juga menyebut bahwa zakat mencakup dua arti (pajak dan zakat) meskipun tidak secara verbal dikatakan bahwa zakat itu pajak. Kata yang dapat mewakili dua arti tersebut adalah "bahwa zakat itu hak fakir pada harta orang kaya" yang berarti bahwa ada kewajiban distribusi terhadap sebagian harta seseorang. Aspek distribusi ekonomi inilah unsur kesamaan yang urgen sebagaimana diungkapkan oleh ahli-ahli keuangan mengenai pajak konvensional dan asas wajib pajak menurut hukum. Dengan perbandingan ini menegaskan bahwa zakat adalah pajak suci yang memiliki ciri dan falsafah khusus atau khas. ${ }^{6}$

Sedangkan pajak menurut hukum positif atau hukum negara yang diatur dalam UU RI Nomor 6 tahun 1983 yaitu UU KUP Pasal 1 Bab 1 tentang Ketentuan Umum dan Tata Cara Perpajakan yang telah diubah terakhir dengan UU RI Nomor 16 tahun 2009.

1. Pajak adalah kontribusi wajib kepada negara yang terutang oleh orang pribadi atau badan yang bersifat memaksa berdasarkan UU dengan tidak mendapatkan imbalan secara langsung dan digunakan untuk keperluan negara bagi sebesar-besarnya kemakmuran rakyat.

2. Wajib pajak adalah orang pribadi atau badan, meliputi pembayar pajak, pemotong pajak, dan pemungut pajak, yang mempunyai hak dan kewajiban perpajakan sesuai dengan ketentuan peraturan perundang-undangan perpajakan.

\footnotetext{
${ }^{6}$ Yûsuf al-Qaradhawi. 2010. Hukum Zaka. Jakarta: Litera Antarnusa, hlm. 1006-1008.
} 
3. Pengusaha Kena Pajak (PKP) adalah pengusaha yang melakukan penyerahan Barang Kena Pajak (BKP) dan/atau Jasa Kena Pajak (JKP) yang dikenai pajak berdasarkan UU Pajak Pertambahan Nilai (PPN) 1984 dan perubahannya.

Sedangkan penggunaan dari pajak diatur dalam PP RI Nomor 45 tahun 2013 tentang Tata Cara Pelaksanaan Anggaran Pendapatan dan Belanja Negara yaitu di Bab IV tentang Pelaksanaan Anggaran Pendapatan. Mengenai pelaksanaan anggaran belanja tercantum dalam Bab V Pelaksanaan Anggaran Belanja.

Mengenai segala yang berhubungan dengan zakat, telah diatur dalam Al-Quran surat AtTaubah 60,

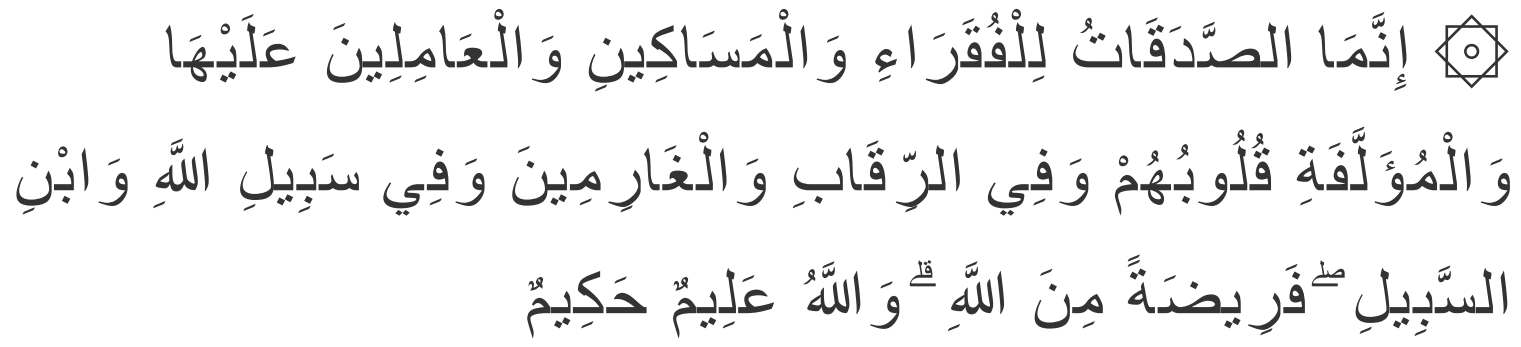

Sesungguhnya zakat-zakat itu, hanyalah untuk orang-orang fakir, orang-orang miskin, pengurus-pengurus zakat, para mu'allaf yang dibujuk hatinya, untuk (memerdekakan) budak, orang-orang yang berhutang, untuk jalan Allah dan untuk mereka yuang sedang dalam perjalanan, sebagai suatu ketetapan yang diwajibkan Allah, dan Allah Maha Mengetahui lagi Maha Bijaksana.

Pengelolaan zakat mengalami perkembangan yang dinamis sesuai dengan perubahan kondisi politik dan ekonomi di Indonesia. Perkembangan tersebut puncaknya terjadi pada tahun 1999 UU No. 38 Tahun 1999 tentang Pengelolaan Zakat yang disusul dengan Keputusan Menteri Agama No. 581 Tahun 1999. Pada masa ini muncul Lembaga Amil Zakat (LAZ) yang telah disahkan, yakni: 1) Dompet Duafa, 2) Yayasan Dana Sosial al-Falah, 3) Yayasan Amanah Takaful, 4) LAZ Persatuan Islam (PERSIS), 5) LAZ Yayasan Bangun Sejahtera Mitra Umat, 6) Yayasan Baitul Maal Muamalat, 7) Yayasan Baitul Maal Ummat Islam (BAMUIS) PT BNI (Persero) Tbk, 8) Pos Keadilan Peduli Ummat (PKPU), 9) LAZ Yayasan Baitul Maal Bank Rakyat Indonesia, 10) Yayasan Baitul Maal Hidayatullah, 11) LAZ Dewan Dakwah Islamiyah Indonesia, 12) LAZ Baitul Maal 
Wat Tamwil (BMT), 13) LAZIS Muhammadiyah, 14) LAZ Baituzzakah Pertamina (BAZMA), 15) LAZ Yayasan Dompet Sosial Ummul Quro (DSUQ), 16) LAZ Ikatan Persaudaraan Haji (IPHI), 17) LAZ Dompet Peduli Ummat Daarut Tauhid (DPUDT), dan 18) LAZ Nahdlatul Ulama (NU). ${ }^{7}$

Dalam Peraturan Pemerintah (PP) No.60 tahun 2010 tentang Zakat Atau Sumbangan Keagamaan Yang Sifatnya Wajib Yang Dapat Dikurangkan Dari Penghasilan Bruto. Peraturan Pemerintah inilah sebenarnya yang merupakan ketentuan pelaksanaan dari Pasal 9 ayat (1) Keputusan Dirjen Pajak No. KEP-163/PJ/2009. Peraturan di atas belum terlaksana karena terkendala:

1. Masih terjadinya perdebatan di kalangan ulama terkait dengan integrasi zakat dan pajak.

2. Manajemen pengelolaan zakat yang masih konvensional dan mengesampingkan akuntabilitas dan transparansi.

3. Intensifitas sosialisasi regulasi pemerintah yang kurang.

4. Regulasi setengah hati pemerintah terhadap pengintegrasian zakat dan pajak.

Selain persoalan di atas, masalah pengelolaan zakat yang masih simpangsiur dengan menggunakan 2 pintu sehingga ada keengganan dari muzakki untuk menyalurkan zakatnya. Semoga dengan adanya Undang-undang No. 38 Tahun 1999 tentang Pengelolaan Zakat diharapkan dapat memperjelas tentang pendistribusian dan pengelolaan zakat yang transparan, maka yang dimaksud "Pengelolaan Zakat" adalah kegiatan yang meliputi perencanaan, pengorganisasian, pelaksanaan, dan pengawasan terhadap pendistribusian serta pendayagunaan zakat.

Zakat merupakan kewajiban berupa ibadah mahdhah yang merupakan bagian dari menyempurnakan rukun Islam yang berefek pada ekonomi dan sosial masyarakat. Dalam ibadah selain vertikal (ibadah antara manusiaa dengan Tuhannya) harus disertai dengan ibadah horizontal (ibadah yang antara manusia dengan manusia yang berimplikasi sosial), maka dari itu Islam disebur sebagai (rahmatan lil 'âlamîn). Kesediaan manusia sebagai

\footnotetext{
${ }^{7}$ Cahyo Budi Santoso. Gerakan Zakat Indonesia. dalam http://dsniamanah.or.id/web/content/view/105/1/. Diakses tanggal 29/01/2020.
} 
seorang muslim yang harus menyisihkan sebagian hartanya untuk kaum fakir dan miskin yang berupa zakat, shodaqoh dan infak merupakan indikator keimanan dan ketakwaan terhadap Allah Swt. Dalam al-Qur'an Allah berfirman dalam al-Qur'an Surat at-Taubah ayat 10:

“Ambillah zakat dari sebagian harta mereka, dengan zakat itu kamu membersihkan dan mensucikan mereka dan berdoalah untuk mereka. Sesungguhnya doa kamu itu (menjadi) ketenteraman jiwa bagi mereka. dan Allah Maha mendengar lagi Maha Mengetahui”.

Maksud dari kata 'membersihkan' dari ayat ini bahwa zakat itu membersihkan mereka yang sebagai hamba Alloh untuk senantiasa bersikap dermawan karena harta hanyalah titipan, untuk itu harus menghindari sifat kekikiran dan cinta yang berlebihlebihan kepada harta benda. Sedangkan maksud kata 'mensucikan' dalam ayat ini bahwa zakat itu dapat berefek positif bagi mereka yang melaksanakannya, menjadi kebaikan dalam hati mereka dan memperkembangkan harta benda mereka. Membersihkan harta juga berarti membersihkan dari unsur-unsur riba. Pada dasarnya manfaat perintah zakat adalah melahirkan sikap positif berupa meninggalkan praktik-praktik riba, membangun jalinan sosial dan jaminan ekonomi serta melibatkan peranan negara. Adapun penjelasannya adalah sebagai berikut:

Pertama, larangan riba, hal ini dimaksudkan untuk menghindari praktek riba yang kenyataannya sangat merugikan kalangan tertentu dan menguntungan kalangan yang lain, hal ini menjadi ketimpangan sosial yang tinggi yang mengakibatkan distorsi perekonomian. Secara mikro ekonomi praktik riba menimbulkan inefisiensi dalam alokasi sumber daya ekonomi yang dapat mengganggu aktivitas dan produktifitas ekonomi menjadi tidak kondusif. Sedangkan secara makro ekonomi praktik riba ini menyebabkan resesi ekonomi sehingga terjadi ketidakseimbangan antara hak dan kewajiban antara pemilik modal dengan para pekerja. $^{8}$

Kedua, kerjasama ekonomi. Manusia merupakan mahluk sosial yang secara fitrah mereka membutuhkan orang lain untuk memenuhi kebutuhan hidupnya, maka diperlukan kerjasama yang saling menguntungkan di antara mereka, jika dalam Islam disebutkan bahwa cintailah saudara muslimmu sebagaimana kerja organ yang saling terkontrol dan

${ }^{8}$ Didin Hafidhuddin. 2012. Zakat dalam Perekonomian Modern, hlm. 68-69. 
terkoordinasi, sakit 1 organ akan dirasakan sakit seluruh anggota badan, begitulah Islam mengajarkan akan pentingnya rasa kesadaran dalam semangat persaudaraan sesama muslim untuk saling membantu dan bekerjasama.

Ketiga, jaminan sosial. Dalam Islam telah ada jaminan sosial yang dilakukan oleh pemerintah untuk keselamatan dan kehormatan dalam kehidupan untuk menjaga kekayaannya. Dalam konteks ini kehidupan sosial dalam Islam sangat harmonis sehingga ada jaminan sosial terhadap individu masyarakat dalam negara.

Keempat, peranan negara. Aturan Islam sangatlah kompleks, salah satunya adalah mengatur dan memberikan peranan kepada negara untuk mengatur rakyatnya agar sejahtera dan harmonis. Negara menjadi regulator tunggal dalam menjalankan roda pemerintahannya untuk mencegah eksploitasi kelompok tertentu terhadap kelompok kecil sehingga tidak terjadi penindasan terstruktur. ${ }^{9}$

Antara pajak dan zakat jika dilihat dari peraturan negara adalah zakat merupakan pengurang dari pajak, sehingga diharapkan dapat memperingan aktivitas ekonomi para wajib pajak tanpa meninggalkan kewajibannya sebagai seorang muslim. Latar belakang zakat menjadi pengurang pajak dijelaskan dalam penjelasan Pasal 14 ayat (3) UU 38/1999 bahwa pengurangan zakat dari laba/pendapatan sisa kena pajak adalah supaya wajib pajak tidak dikenakan pembebanan pembayaran ganda, yakni kewajiban membayar zakat dan pajak. Ketentuan ini masih diatur dalam UU yang terbaru yakni dalam Pasal 22 UU 23/2011 "Zakat yang dibayarkan oleh muzaki kepada BAZNAS atau LAZ dikurangkan dari penghasilan kena pajak."

Hal ini dijelaskan pula dalam ketentuan perpajakan sejak adanya UU No. 17 Tahun 2000 tentang Perubahan Ketiga atas UU No. 7 Tahun 1983 tentang Pajak Penghasilan, yakni diatur dalam Pasal 4 ayat (3) huruf a nomor 1 yang berbunyi: "Yang tidak termasuk sebagai Objek Pajak adalah: bantuan sumbangan, termasuk zakat yang diterima oleh badan amil zakat atau lembaga amil zakat yang dibentuk atau disahkan oleh Pemerintah dan para penerima zakat yang berhak."

\footnotetext{
${ }^{9}$ Fakhruddin. 2008. Fikih dan Manajemen Zakat. Malang: UIN Malang Press, hIm. 252.
} 
Selain itu, Pasal 1 ayat (1) PP No. 60 Tahun 2010 tentang Zakat atau Sumbangan Keagamaan yang Sifatnya Wajib yang Boleh Dikurangkan dari Penghasilan Bruto juga menentukan: "Zakat atau sumbangan keagamaan yang sifatnya wajib yang dapat dikurangkan dari penghasilan bruto meliputi:

a. Zakat atas penghasilan yang dibayarkan oleh Wajib Pajak orang pribadi pemeluk agama Islam dan/atau oleh Wajib Pajak badan dalam negeri yang dimiliki oleh pemeluk agama Islam kepada badan amil zakat atau lembaga amil zakat yang dibentuk atau disahkan oleh Pemerintah; atau

b. Sumbangan keagamaan yang sifatnya wajib bagi Wajib Pajak orang pribadi pemeluk agama selain agama Islam dan/ atau oleh Wajib Pajak badan dalam negeri yang dimiliki oleh pemeluk agama selain agama Islam, yang diakui di Indonesia yang dibayarkan kepada lembaga keagamaan yang dibentuk atau disahkan oleh Pemerintah."

Sedangkan, lembaga yang ditetapkan sebagai penerima zakat atau sumbangan keagamaan yang sifatnya wajib yang dapat dikurangkan dari penghasilan bruto diatur dalam Peraturan Direktur Jenderal Pajak No. PER-15/PJ/2012 yang berlaku sejak tanggal 11 Juni 2012 yang sebelumnya diatur dengan Peraturan Direktur Jenderal Pajak No. PER33/ PJ/2011, lembaga yang keseluruhannya saat ini berjumlah 21 lembaga. Sedangkan mekanisme pengurangan zakat dari penghasilan bruto ini dapat ditemui dalam Peraturan Dirjen Pajak No. PER-6/PJ/2011 Tahun 2011 tentang Pelaksanaan Pembayaran dan Pembuatan Bukti Pembayaran atas Zakat atau Sumbangan Keagamaan yang Sifatnya Wajib yang Dapat Dikurangkan dari Penghasilan Bruto. ${ }^{10}$

Dari segi hukum syariah dan hukum negara, zakat tidak ada perbedaan dari segi pengertian, jenis, macam dan lain sebagainya. Hukum negara memang hanya mengatur dari segi pemungut zakat yang sekarang lebih jelas supaya terjadi efisiensi dan pengaturan yang jelas dalam hal pemungut, dipungut, pengelola dan penerima zakat. Supaya terjadi efektifitas yang reliabel dan dapat dipercaya, akuntabilitasnyapun terpercaya

10 2019. Learning Pajak di www.pajakonline.com/engine/learning. Diakses pada 29/01/2020. 


\section{SIMPULAN DAN SARAN}

Simpulan yang dapat diambil dalam penelitian ini adalah antara pajak dan zakat memiliki kesamaan dan perbedaan yang menonjol dari segi hukum syariah dan hukum negara. Dari kesamaan yang dimiliki, banyak penelitian yang menyarankan untuk memadukan penerimaan pajak dan zakat menjadi penerimaan negara dan negara yang nantinya akan menyalurkan dan mengeluarkan zakat dengan 1 pintu, lembaga yang dibawahi kementrian. Akan tetapi perbedaannya juga menonjol yaitu penggunaan pajak dan zakat yang sangat berbeda sehingga harus dibedakan lembaga yang menanganinya. Pro dan kontra ini menjadi masih menjadi perbincangan hangat di kalangan peneliti dan praktisi.

\section{DAFTAR PUSTAKA}

Al-Qaradhawi, Yûsuf. 2010. Hukum Zakat. Jakarta: Litera Antarnusa, hlm. 1006-1008.

Fakhruddin. 2008. Fikih dan Manajemen Zakat. Malang: UIN Malang Press, hlm. 252.

Hafidhuddin, Didin. 2012. Zakat dalam Perekonomian Modern. Jakarta: Gema Insani Press.

Ramadhan, Muhammad Rheza. Integrasi Pajak dan Zakat di Indonesia. Jurnal Ekonomi Islam Vol. 8 No. 1 Januari-Juni 2017: 77-94.

Santoso, Cahyo Budi, Gerakan Zakat Indonesia, dalam http://dsniamanah.or.id/web/content/view/105/1/. Diakses pada 29/01/2020.

Setiawan, Samhis. 2019. Studi Kepustakaan-Pengertian, Tujuan, Peranan, Sumber dan Strategi di https://www.gurupendidikan.co.id/studi-kepustakaan-pengertian-tujuanperanan-sumber-strategi/. Diakses pada 29/01/2020.

Tahir, Masnun dan Zusiana Elly Triantini. Integrasi Zakat dan Pajak di Indonesia dalam Tinjauan Hukum Positif dan Hukum Islam. Jurnal Al-‘Adalah Vol. XII, No. 3 Juni 2015: 507-524.

Thidi. 2018. Persamaan dan Perbedaan Pajak dengan Zakat di https://thidiweb.com/persamaan-dan-perbedaan-pajak-dengan-zakat/. Diakses pada 29/01/2020.

Wahid, Moh. Abdur Rohman. Integrasi Pajak dan Zakat di Indonesia Perspektif Hukum Islam dan Hukum Positif. Jurnal Ekonomi Islam el-Jizya Vol. 4 No.1 Januari-Juni 2016: 27-58.

2009. UU RI Nomor 6 tahun 1983 yaitu UU KUP Pasal 1 Bab 1 tentang Ketentuan Umum dan Tata Cara Perpajakan yang telah diubah terakhir dengan UU RI Nomor 16 tahun 2009.

2013. PP RI Nomor 45 tahun 2013 tentang Tata Cara Pelaksanaan Anggaran Pendapatan dan Belanja Negara yaitu di Bab IV tentang Pelaksanaan Anggaran Pendapatan. Mengenai pelaksanaan anggaran belanja tercantum dalam Bab V Pelaksanaan Anggaran Belanja.

. 2009. Undang-Undang No.16 tahun 2009 tentang Ketentuan Umum dan Tata Cara Perpajakan pasal 1. . 2019. www.pajakonline.com/engine/learning. Diakses pada 29/01/2020. 